\title{
Sustainable Development of Logistic Infrastructure of the Region
}

\author{
Vera Borisova and Natalya Pechenko* \\ Saint Petersburg State University of Economics, 191023 St. Petersburg, Russia
}

\begin{abstract}
In recent decades, the speed of transformation of logistics infrastructure facilities has radically changed in Russia and its regions. The transformation of the logistics infrastructure led to the widespread use of artificial material means and resource-intensive production, the depletion of non-renewable natural resources, which led to the deterioration of the ecological state of the environment. Such development of systems is characterized by specialists as a technogenic type of ecological and economic management. Human activity in the context of the development of an economic system of a technogenic type leads to the destruction of the biosphere, environmental pollution and the destruction of the ecology of territories. The data of the state report "On the state and protection of the environment of the Russian Federation in 2019", formed by the Ministry of Natural Resources and Ecology of the Russian Federation, indicate a high degree of environmental pollution in the Russian Federation with a positive trend towards reduction. A possible solution to the problem of environmental pollution in the development of the logistics infrastructure of the region is to refer to world practices, namely to the concept of sustainable development. The basis of this concept lies in the sustainable development of all spheres of human life by maintaining a balance between the ecological, economic, social, cultural development of the region and the needs of people, in terms of efficient use of natural resources, energy-saving and environmental technologies, support of society, development of human resources, support of features cultural potential, preserving the integrity of the environment and biosphere for future generations.
\end{abstract}

\section{Introduction}

In 2021, sustainable development issues became the agenda of many social institutions. The pandemic and coronavirus have put scientists and practitioners in front of the need to rethink the concept of "sustainability of the logistics system". Many logistics companies began to rebuild their business after the crisis on the principles of environmental, social and corporate cooperation ESG, Environmental, Social, Governance.

\footnotetext{
*Corresponding author: natalya-oteva@yandex.ru
} 
In the context of the implementation of these principles by the leading countries of the world, it is planned to reduce greenhouse gas emissions, up to a complete cessation by 2050 .

The Russian economy and its logistics sector are only at the beginning of the path to apply ESG principles in their activities. Sustainable environmentally friendly infrastructure facilities are expensive and at the same time low-profit projects. Herewith, the environmental potential of Russian technologies is estimated by experts at more than three RUR trln.

It is obvious that the state of instability of logistics systems is increasing at bifurcation points, and now there is an urgent need to make a choice, or to correct the path of development of logistics infrastructure facilities. The importance of considering bifurcation points is that they allow the possibility of influencing the choice of the system's behavior, its further development, by means of non-force, informational methods, "weak" influences.

Investigating the problem of sustainable development of the region's infrastructure, the authors focus on the transport and logistics segment of the economy. This sector of the region's logistics infrastructure, on the one hand, is a driving force and tool for solving environmental, economic, social and cultural problems, on the other hand, it negatively affects the environment of the territory. Therefore, the search for ways to form a sustainable logistics infrastructure of the ESG format in the region is of particular importance today. This circumstance determines the relevance of the topic of this study.

\section{Research Methodology}

To reveal the problem of sustainable development of the region's logistics infrastructure, we turned to the tools, methods and knowledge of various sciences (interdisciplinary knowledge), which make it possible to shed light on the solution of the task: logistics, ecology, economic theory, management. The study was based on regulatory documents, legislative acts, government reports, research work in the field of assigning ESG ratings to companies, materials for the development of logistics infrastructure, transport system, the concept of sustainable development, environmental protection and human health. Research ideas about the sustainable development of the region's logistics infrastructure are formed on the basis of aggregate knowledge of the existing ecological and economic problems of the region, the study of the impact of the logistics infrastructure on the environment and human well-being, and an assessment of the possibility of building a logistics infrastructure based on the concept of sustainable development. The totality of the above scientific provisions determined our position, as well as theoretical and applied substantiation of the problem under study.

\section{Findings}

The task of forming the infrastructural framework of the Russian regions is aimed at the uninterrupted, comprehensive movement of resource flows that ensure the progressive development of the country's economy. This task is related to the implementation of national projects: "Safe and high-quality highways", "Modernization of passenger transport in urban agglomerations" and "Development of the federal backbone network". It is obvious that the dynamic development of regions, an increase in production capacity, the modernization of production processes, an increase in export-import capabilities largely depends on the logistics infrastructure, as a factor in increasing the efficiency of activities [1]. Now in Russia, the first projects are being implemented to launch unmanned vehicles, autonomous taxis, and unmanned cargo transportation. The digital transformation of 
logistics processes permeates the entire path of movement of commodity flows - from the source of raw materials to the end consumer. Electronic document flow, online delivery and cargo clearance capabilities contribute to efficient goods flow. Perfect logistics infrastructure for the regional economy is a guarantee of a competitive advantage through the creation of developed transport networks, modern multifunctional logistics parks, software and hardware [2, 3].

In research developments it is noted that "the efficient use of warehouse, transport and information logistics infrastructure reduces the need for logistics capacity and, accordingly, helps to reduce infrastructure costs, increasing the profitability of assets with the same sales volume" [4].

The analysis showed that highly specialized intermediaries still dominate the Russian market of logistics services. They provide traditional types of services, performing one or several logistic functions: organizing the spatial movement of goods, forwarding, warehousing, cargo handling, etc. Logistics operators for the delivery and forwarding of goods dominate the total market share of logistics services $[5,6]$.

Consider the dynamics of freight turnover by types of public transport in the Russian Federation, as the largest segment of the region's logistics infrastructure (Figure 1).
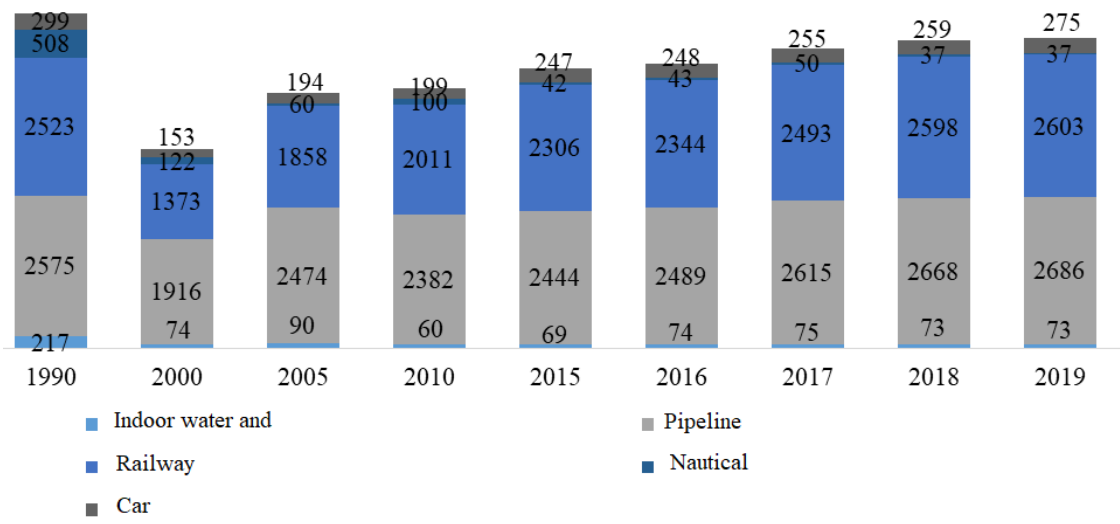

Fig. 1. Dynamics of freight turnover by types of public transport in the Russian Federation, 19902019, bln tkm [7]

In 2019, pipeline transport accounts for the largest share of all types of transport $47.3 \%$ or $2,686.2 \mathrm{bln} \mathrm{tkm}$. The indicator of pipeline transport has increased since 2010 by 304.1 bln tkm.

Thus, pipeline transport occupies a leading position in terms of cargo turnover in 2019. The second place is occupied by railway transport, the indicator of which was 2,602.5 bln tkm.

The technical condition and capacity of existing vehicles is of great importance for ensuring the sustainable development of the region's logistics infrastructure, and in the context of environmental protection, it is also necessary to pay attention to the types of fuel used (table 1).

Table 1. Age structure of vehicles in the Russian Federation, 2019, \% [7]

\begin{tabular}{|l|r|r|c|}
\hline \multirow{2}{*}{ Age category of vehicles } & \multirow{2}{*}{\begin{tabular}{c} 
Share in total \\
number of \\
\cline { 3 - 4 }
\end{tabular}} & \multicolumn{2}{|c|}{ Including } \\
\cline { 3 - 4 } & vehicles & natural & legal \\
persons & entities \\
\hline manufactured 1 year ago, including & 9.2 & 8.9 & 13.3 \\
\hline
\end{tabular}




\begin{tabular}{|l|r|r|r|}
\hline manufactured within 1-3 years ago, including & 9.2 & 8.7 & 13 \\
\hline manufactured within 3-5 years ago, including & 9.1 & 8.9 & 10.2 \\
\hline $\begin{array}{l}\text { manufactured within 5-10 years ago, } \\
\text { including }\end{array}$ & 21.6 & 21.8 & 18.9 \\
\hline $\begin{array}{l}\text { manufactured within 10-15 years ago, } \\
\text { including }\end{array}$ & 16.8 & 17.3 & 11.8 \\
\hline $\begin{array}{l}\text { manufactured more than 15 years ago, } \\
\text { including }\end{array}$ & 34 & 9 & 13.3 \\
\hline All age categories of vehicles & 100 & 100 & 100 \\
\hline
\end{tabular}

The share of vehicles under 5 years old is one fourth $(27.5 \%)$ of the total; vehicles over 5 years old make up $72.5 \%$ of the total. The leading position in this category is occupied by transport over 15 years old (34.0\% of the total), slightly inferior to it is transport aged from 5 to 10 years $(21.6 \%)$. In general, a similar age structure of transport is observed in the context of forms of ownership.

The types of motor fuels used by vehicles also play a significant role in the formation of emissions of pollutants into the atmosphere [8] (table 2).

The data in Table 2 allow us to note that only $3 \%$ of all transport provides for the possibility of using natural gas, liquefied hydrocarbon (petroleum) gas as fuel, as well as the use of electric motors.

The development of the region's logistics infrastructure should not contradict the principles of environmental protection and human health, disrupt the biosphere and lead to irreversible consequences. The greatest harm to the environment is caused by freight transport by various modes of transport.

The total volume of emissions of pollutants into the air by the type of economic activity "transportation and storage" amounted to $1,863.6$ th $\mathrm{t}$ in 2019 , which is $4.5 \%$ more than in $2018(1,783.2$ th $\mathrm{t})$. Of the total emissions, rail transport only accounts for about $1 \%$ of emissions, while land and pipeline transport accounts for $93.5 \%$ of emissions.

Table 2. Structure of vehicles in the Russian Federation by types of motor fuel, 2019, \% [7]

\begin{tabular}{|c|c|c|c|}
\hline \multirow[b]{2}{*}{ Vehicles by types of the used motor fuel } & \multirow{2}{*}{$\begin{array}{c}\text { Share in total } \\
\text { number of } \\
\text { vehicles }\end{array}$} & \multicolumn{2}{|c|}{ Including } \\
\hline & & $\begin{array}{l}\text { natural } \\
\text { persons }\end{array}$ & $\begin{array}{c}\text { legal } \\
\text { entities }\end{array}$ \\
\hline $\begin{array}{l}\text { With a possibility of use of natural gas and the } \\
\text { liquefied hydrocarbon (oil) gas }\end{array}$ & 3.3 & 3.2 & 3.8 \\
\hline With the possibility of using electric motors & 0.05 & 0.05 & 0.04 \\
\hline $\begin{array}{l}\text { With the possibility of using only gasoline and } \\
\text { diesel fuel }\end{array}$ & 96.6 & 96.7 & 96.1 \\
\hline All types of vehicles & 100 & 100 & 100 \\
\hline
\end{tabular}

Pursuant to the order of Rosprirodnadzor dated 01/11/2013 No. 6-p, in the Russian Federation, since 2013, work has been performed annually to assess emissions from certain types of mobile sources as part of road and rail transport.

Thus, motor transport is one of the main sources of air pollution in large cities of the country. Since 2013, the volume of emissions from road transport continued to increase and in 2018 amounted to $15.1 \mathrm{mln} \mathrm{t}$, but in 2019 it sharply decreased and amounted to 5,291 th $\mathrm{t}$ (figure 2). 


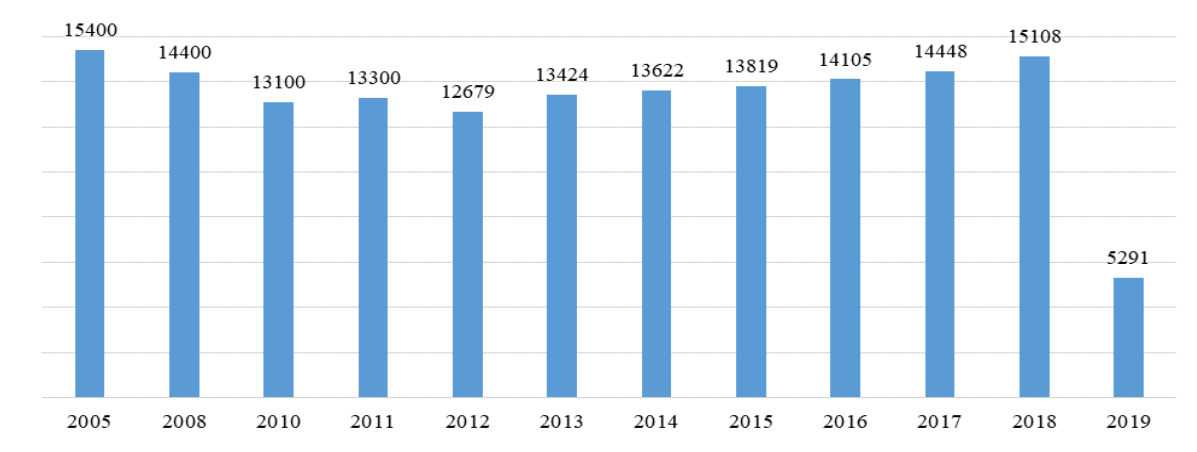

Figure 2. Dynamics of emissions of pollutants by vehicles into the atmosphere of the Russian Federation, 2005-2019, th $\mathrm{t}[7]$

Rosprirodnadzor data on emissions of pollutants into the atmosphere from vehicles indicate that the largest volumes of emissions are in the Central Federal District. In 2014, it accounted for $26.5 \%$ of all emissions from the country's vehicles, and in $2019-24.6 \%$. The second place is taken by the Volga Federal District; its share in 2014 and 2019 was at the level of $20.2 \%$.

Moscow is the leader among the Russian Federation constituent entities in terms of emissions from vehicles. Pursuant to Rosprirodnadzor, Moscow accounted for 334.4 th $t$ in 2019, i.e 25.7\% of all pollutant emissions from cars in the Central Federal District. Together with emissions from vehicles in the Moscow region (221.4 th $t$ in 2019), emissions from the Moscow region account for about $43 \%$ of all vehicle emissions in the Central Federal District and about one tenth of the total Russian value. The share of emissions from vehicles in St. Petersburg and the Leningrad Region in the total Russian volume is much lower; emissions from this region account for about $32.4 \%$ of emissions from the Moscow region.

Let us sum up the preliminary result: the logistics infrastructure of the region functions in specific social-and-economic and natural-climatic conditions and its systemic sustainability is ensured by environmentally sound management of goods movement, the use of alternative energy sources, environmentally friendly transport and resource saving technologies.

\section{Result discussion}

From the standpoint of the concept of sustainable development, the logistics infrastructure of the region should develop in a balanced manner in relation to all spheres of human life by maintaining a balance between economic, environmental, social, and cultural development.

From this point of view, the logistics infrastructure of the region is a network of interconnected elements that make up a single regional transport and logistics space in order to establish sustainable economic growth, enhance the cultural, social level of development of the region [9].

To create a modern sustainable logistics infrastructure in the region, it is necessary to use the latest technologies and tools to enhance the quality of the logistics services provided, as well as to allocate a large share to management and integrated logistics [10, $11]$.

Connecting logistics tools for resource saving "allows to reduce stocks of materials by $40-60 \%$, accelerate the turnover of working capital by $20-40 \%$, and reduce transportation 
costs by $7-20 \%$. There is a large reserve (15-30\%) and from reducing the cost of loading and unloading operations and from rationalizing the storage system of material resources" [12].

Consider the possible threats to the formation of a logistics infrastructure pursuant to the concept of sustainable development:

- worn-out vehicles included in the transport and logistics space of the region;

- insufficient control over the movement of hazardous substances and hazardous waste for the environment;

- formal control over the time of work and rest of vehicle drivers;

- non-compliance of vehicles with world standards in terms of environmental pollution and technological parameters;

- underdeveloped logistics infrastructure in the regions located far from the central cities;

- insufficient number of transport highways that meet international quality standards, as well as poor quality of the asphalt road surface, which leads to a high rate of accidents on the highways;

- legal conflicts between national legislation and the world legal system;

- regular challenges to society in the form of terrorist acts, extremist threats, man-made disasters, political sanctions.

The threats to the sustainable development of the region's logistics infrastructure that we have identified allow us to identify the following pressing problems:

- insufficient financing of development of road infrastructure;

- insufficient level of technical and technological development of vehicles;

- insufficient introduction of vehicles with alternative fuel sources, as well as underdeveloped infrastructure of alternative fuel filling stations;

- low level of complex and management logistics;

- low level of interaction between participants of logistic infrastructure.

\section{Conclusion}

It goes without saying that it is quite difficult to create a favorable logistics infrastructure based on the concept of sustainable development in a constantly changing world with various world crises, armed conflicts, political sanctions, a worsening epidemiological situation, as well as due to the unpredictability of the coronavirus pandemic. However, the solution to the above problems is possible due to the following factors in the development of the region's logistics infrastructure:

1.The use of modern information technologies, the latest logistics concepts, the best world practices in the formation of the logistics infrastructure of the region.

2.Active and coordinated planning for the development of the region's logistics infrastructure between government agencies and business entities.

3.Increase in a share of complex and management logistics.

4.Creation of a single integrated logistic platform for interaction of participants in the region's logistic infrastructure.

5.Implementation of mandatory standardization and certification of logistics services provided in the transport and logistics industry of the region.

6.Improvement of a standard and legal system in the field of logistics.

7. Performance assessment based on ESG principles.

Therefore, the sustainable development of the region's logistics infrastructure includes a set of aspects of technical and economic, resource-saving and environmental and social efficiency, which is implemented with the joint cooperation of all interested business entities and public authorities. 
The article was prepared with the support of the Russian Foundation for Basic Research (project No. 20-010-00141/20 "Formation of the institutional framework of the regional infrastructure in the digital economy". «The reported study was funded by RFBR,project number 20-010-00141120».

\section{References}

1. V.V. Borisova, N.S. Pechenko, A.V. Molonova, International Conference on Digital Transformation in Logistics and Infrastructure (ICDTLI 2019). Atlantis Highlights in Computer Sciences, 1, 20 (2009)

2. N.O. Starkova, M.A. Vyshenskaya, Nauchnye meridiany Sbornik materialov II Mezhdunarodnoj nauchno-prakticheskoj konferencii, 173 (2016)

3. N.A. Osincev, E.V. Kazarmshchikova, Faktory ustojchivogo razvitiya transportnologisticheskih system, 1 (SPTKR, 2017)

4. V.V. Borisova, K.G. Gordei, Science of the XXI century: problems and prospects of researches, 2, 3 (2017)

5. V. Borisova, K Taymashanov, T Tasueva, Czech Republic. Sustainable Leadership for Entrepreneurs and Academics, (Springer Proceedings in Businessand Economie AG, 2019)

6. I.G. Rzun, N.O. Starkova, Vestnik NGIEI, 11, 89 (2016)

7. O sostoyanii i ob ohrane okruzhayushchej sredy Rossijskoj Federacii v 2019 godu. Gosudarstvennyj doklad, Minprirody Rossii, MGU imeni M.V. Lomonosova (2020)

8. YU.V. Bubnov, A.A. Kizim, N.O. Starkova, Politematicheskij setevoj elektronnyj nauchnyj zhurnal Kubanskogo gosudarstvennogo agrarnogo universiteta, 88, 395 (2013)

9. A.A. SHkonda. Byulleten' nauki i praktiki, 4 (1), 219-227 (2018)

10. A.D. Moiseyev, I.F. Narizhny, Central scientific bulletin, 19(36) (2017)

11. D. I. Potapov, A. I. Potapov, Molodoj uchenyj, 46 (232), 383 (2018)

12. V.V. Borisova, Vestnik RGEU (RINH), 2, 45 (2020) 